\title{
Culture and the Human Rights of Women in Africa: Between Light and Shadow
}

\author{
Manisuli Ssenyonjo*
}

\begin{abstract}
Despite the ratification by African states of several human rights instruments protecting the human rights of women in Africa, and the solemn commitment of the African states to eliminate all forms of discrimination and harmful practices against women, women in Africa still continue to experience human rights violations. Most African women are denied the equal enjoyment of their human rights, in particular by virtue of the lesser status ascribed to them by tradition and custom, or as a result of overt or covert discrimination. Many women in Africa experience distinct forms of discrimination due to the intersection of sex with such factors as race, language, religion, political and other opinion, national or social origin, property, birth, or other factors, such as age, disability, marital, refugee or migrant status, resulting in compounded disadvantage. Therefore, much remains to be done to realize the human rights of women in Africa. This article examines the relationship between culture and women's human rights, and makes some recommendations for the effective realization of these rights.
\end{abstract}

\section{INTRODUCTION}

In 1995, the United Nations reported "in no society today do women enjoy the same opportunities as men". ${ }^{1}$ More than ten years later, discrimination against women persists not only in the developing African states, ${ }^{2}$ but also in the more developed states including Germany ${ }^{3}$ and

* Lecturer in law, School of Law, Brunel University, West London.

1 United Nations Development Programme (UNDP) Human Development Report 1995: Gender and Human Development (1995) at 29, available at: < http://hdr.undp.org/reports/global/ 1995/en/> (last accessed 12 March 2006). The term "women" is used in this article to include girls.

2 S Tamale "Gender trauma in Africa: enhancing women's links to resources" (2004) 48/1 Journal of African Law 50.

3 In 2001, for example, the UN Committee on Economic, Social and Cultural Rights (CESCR) observed: "Like the ILO [International Labour Organization], the Committee is concerned about the persisting impediments to women in German society, in terms of promotion in employment and equal wages for work of equal value, both in the private and public sectors, and especially in federal bodies and academic institutions, despite the efforts of the State party to give a new impetus to the equal participation of women in the labour market". See CESCR Concluding Observations: Germany E/C12/1/Add68 (24 September 2001) at para 19. See also Human Rights Committee (HRC) Concluding Observations: Germany CCPR/CO/80/DEU (4 May 2004) at para 13, noting that the "number of women in senior positions is still very low" and that there are "wide disparities, in the private sector, of remuneration between men and women". 
Luxembourg.4 In a 2002 Joint Declaration of Special Rapporteurs on Women's Rights, it was noted that:

"Violence against women and girls is perpetrated in every country in the world. This occurs in situations of peace and conflict. However, the State agents and private actors responsible are not held to account. This climate of impunity encourages the persistence of such violations". ${ }^{5}$

As the Parliamentary Assembly of the Council of Europe has pointed out, although slavery was officially abolished more than 150 years ago, "domestic slavery" persists in Europe and concerns thousands of people, the majority of whom are women. ${ }^{6}$ This is also true in other jurisdictions. In Africa, for example, the consequences of slavery still persist in some states such as Mauritania to the detriment of women. ${ }^{7}$ In every state where data is available, for example, notwithstanding favourable legislation, women's average wages are less than those of men regardless of education, ${ }^{8}$ and women experience the onus of the "double duty". ${ }^{9}$ Over 60 per cent of those working in family enterprises without pay are women. ${ }^{10}$ Women are often subjected to discriminatory employment practices such as the requirement to present a non-pregnancy certificate to gain employment

4 CESCR Concluding Observations: Luxembourg E/C.12/1/Add 86 (23 May 2003) at para 22: “The Committee notes with concern that women are still underrepresented in the work force. While taking note that the disparities between wages of men and women have been reduced, the Committee also notes with concern that the current level of wage difference (women receiving 15 per cent lower wages than men) remains a matter of concern".

5 United Nations, Joint Declaration of Special Rapporteurs on Women's Rights, 8 March 2002, available at: <http://www.un.org/news/Press/docs/2002/wom1330. doc.htm $>$. The Declaration was made by Ms Marta Altolaguirre, special rapporteur on women's rights, Inter-American Commission on Human Rights; Ms Radhika Coomaraswamy, special rapporteur on violence against women, its causes and its consequences, UN Commission on Human Rights; and Ms Angela Melo, special rapporteur on the rights of women in Africa, African Commission on Human and Peoples' Rights.

6 European Court of Human Rights (ECtHR) Siliadin v France Appl No 73316/01 (judgment of 26 July 2005) at para 111.

7 African Commission on Human and Peoples' Rights (ACHPR) Bah Ould Rabah v Mauritania Communication 197/97 (2005) 12 International Human Rights Reports 872 at para 29.

8 UN Development Fund for Women (UNIFEM) Progress of the World's Women (2000, United Nations) at 92.

9 AM Cotter Gender Injustice: An International Comparative Analysis of Equality in Employment (2004, Ashgate Press) at 93-215. "Double duty" refers to the reality that women worldwide who join the paid labour force nevertheless continue to shoulder more than their fair share of household and family responsibilities.

10 See United Nations The Millennium Development Goals Report 2005 (2005, United Nations) at 16, available at: < http://unstats.un.org/unsd/mi/pdf/MDG\%20Book.pdf $>$ (last accessed 21 March 2006), noting that: "In the home, women perform most of the chores. This work is also unpaid, often little valued and not reflected in national production statistics". 
or to avoid dismissal from employment. ${ }^{11}$ Thus, notwithstanding comprehensive international and domestic laws proscribing sex discrimination and promoting equality, women's human rights are "systematically denied"12 and "women [are] poorer than men across class, race, national, economic and ethnic lines". ${ }^{13}$ It is not surprising that women are generally "over-represented in low-paid employment". ${ }^{14}$ Despite significant achievements in the quest for women's equality, and in particular the entry into force of the Convention on the Elimination of All Forms of Discrimination against Women (CEDAW) ${ }^{15}$ which was accepted by 185 states by October 2006 , ensuring gender equality in all states remains an enormous challenge. ${ }^{16}$

This article examines the relationship between culture and the realization of the human rights of women in Africa. As space does not permit, the intention is not to address all cultural issues, but to consider some cultural obstacles and threats that have caused major difficulties. Although African states have ratified several human rights instruments protecting women's human rights, generally the severe political, economic and social difficulties facing African states have had a negative impact on the efforts to respect, protect and fulfil the human rights of women. The prevalence of prejudicial traditional practices and customs that legitimize women's inequality in rural areas of most African states hamper the effective implementation of human rights generally, and of women as a vulnerable group in particular. Although obstacles to the realization of both the civil and political rights (CPR) and the economic, social and cultural rights (ESCR) of women, traditional practices and customs disproportionately affect ESCR since traditionally this category of rights has been often marginalized rather than prioritized. ${ }^{17}$ Most violations of ESCR (for

11 CESCR Concluding Observations: Mexico Future E/C12/CO/MEX/4 (17 May 2006) at para 15: "The Committee reiterates its concern about the practice of employers in the maquiladora (textile) industry to require women to present non-pregnancy certificates in order to be hired or to avoid being dismissed".

12 Human Rights Watch "Women's rights in Middle East and North Africa", available at: $<$ http:www.hrw.org/women/overview-mena.html> (accessed 17 March 2006). See also Amnesty International Human Rights for Human Dignity: A Primer on Economic, Social and Cultural Rights (2005, Amnesty International Publications) at 50-51.

13 Cotter Gender Injustice, above at note 9 at 273 (footnote omitted).

14 CESCR Concluding Observations: Liechtenstein Future E/C.12/CO/LIE/1 (19 May 2006) at para 13.

15 GA res 34/180, 34 UN GAOR Supp (No 46) at 193, UN Doc A/34/4.

16 United Nations Press Release "High Commissioner for Human Rights points to challenges and opportunities in promoting women's rights" (8 March 2006), available at: $<$ http://www.unhchr.ch/huricane/huricane.nsf/view01/754BA777E8ACE0A6C125712B00 4B0387?opendocument> (accessed 12 March 2006). See also R Rebouche "Labour, land, and women's rights in Africa: challenges for the new Protocol on the Rights of Women" (2006) 19 Harvard Human Rights Journal 235.

17 See, eg, J Oloka-Onyango "Reinforcing marginalized rights in the age of globalization: international mechanisms, non-state actors and the struggle for peoples' rights in Africa" (2003) 18/4 American University International Law Review 851; S Skogly "Crimes against humanity-revisited: is there a role for economic and social rights" (2001) 5/1 International Journal of Human Rights 58. 
example, the right to education which plays "a vital role in empowering women" to participate fully in their communities) ${ }^{18}$ often continue unchallenged since they are regarded as not justiciable and thus "notquite-rights". ${ }^{19}$ The overwhelming majority of children deprived of basic education and illiterate adults are female. ${ }^{20}$ In Togo, for example, there is an extremely high rate of illiteracy among women, which in 1998 stood at 60.5 per cent in the rural areas and 27.6 per cent in the urban areas. ${ }^{21}$ The denial of women's ESCR in turn undermines women's ability to enjoy their CPR, which then limits women's capacity to influence decision and policy making in public life. ${ }^{22}$ This article concludes with observations and recommendations to address these obstacles so that African states comply with their domestic, regional and international human rights obligations relating to the protection and promotion of women's human rights.

\section{HUMAN RIGHTS OF WOMEN IN AFRICA: AN OVERVIEW}

In view of the fact that all human beings are born "free and equal in dignity and rights", ${ }^{23}$ the principles of non-discrimination and equality represent the "twin pillars" upon which the whole edifice of human rights law is established. ${ }^{24}$ These two principles are included in various international and regional human rights instruments. ${ }^{25}$ The main women's human rights instruments in Africa - most notably the African Charter on Human

18 CESCR General Comment 13: The Right to Education (21st session, 1999) UN Doc E/C.12/1999/ 10 (1999) at para 1.

19 K Tomasevki "Has the right to education a future within the United Nations? A behindthe-scenes account by the special rapporteur on the right to education 1998-2004", (2005) 5/2 Human Rights Law Review 205 at 216, noting that: "As the Cold War has not ended as yet within the [UN Commission on Human Rights], economic, social and cultural rights are still a casualty".

20 K Watkins The Oxfam Education Report (2000, Oxfam) at 3: "Two-thirds of the children not in school - and a similar proportion of adults who are illiterate - are female".

21 CEDAW Concluding Observations: Togo CEDAW/C/TGO/CO/3 (3 February 2006) at paras 2425. Togo's Ministry of Education circular No 8478/MEN-RS prohibits pregnant schoolgirls or students from attending school. This partly accounts for the high dropout rate of girls and their low enrolment rates in higher education owing to pregnancy and early and forced marriage.

22 See "Montreal Principles on Women's Economic, Social and Cultural Rights" (2004) 26 Human Rights Quarterly 760 at 763 [hereinafter Montreal Principles].

23 Universal Declaration of Human Rights, GA res 217A (III), UN Doc A/810 at 71 (1948) [herein after UDHR], art 1.

24 See J Rehman International Human Rights Law: A Practical Approach (2003, Pearson Education) at 269; A McColgan "Principles of equality and protection from discrimination in international human rights law" (2003) 2 European Human Rights Law Review at 157; M MacEwen "Comparative non-discrimination law: an overview" in $\mathrm{T}$ Loenen and $\mathrm{P}$ Rodrigues (eds) Non-Discrimination Law: Comparative Perspectives (1999, Kluwer) 427.

25 See, eg, The United Nations Charter, 26 June 1945, 59 Stat 1031, TS 993, 3 Bevans 1153, entered into force 24 October 1945, art 1(3); UDHR, art 2; International Covenant on Civil and Political Rights, GA res 2200A (XXI), 21 UN GAOR Supp (No 16) at 52, UN Doc 
and Peoples' Rights (hereafter ACHPR or the Charter), ${ }^{26}$ and the Protocol to the African Charter on Human and Peoples' Rights on the Rights of Women in Africa (hereafter African Women's Rights Protocol or the Protocol) ${ }^{27}$ prohibit discrimination and protect the equal enjoyment of the rights of men and women. ${ }^{28}$

\section{The African Charter on Human and Peoples' Rights and the rights of women in Africa}

The ACHPR contains four main provisions protecting women against discrimination. First is the general non-discrimination clause contained in article 2 of the Charter, which states that: "Every individual shall be entitled to the enjoyment of the rights and freedoms recognised and guaranteed in the present Charter without distinction of any kind such as ... sex". Secondly, this is reinforced by article 3 which deals with equal protection in the following terms: "1. Every individual shall be equal before the law. 2. Every individual shall be entitled to equal protection of the law". Thirdly, for the avoidance of doubt, article 18(3), which generally deals with the protection of the family, states: "The State shall ensure the elimination of every discrimination against women and also ensure the protection of the rights of the woman and the child as stipulated in international declarations and conventions". Finally, article 60 states that the African Commission on Human and Peoples' Rights (the African Commission) will draw inspiration from international human rights instruments (such as CEDAW).

contd

A/6316 (1966), 999 UNTS 171, entered into force 23 March 1976 [hereinafter ICCPR], arts 2(1) and 26; International Covenant on Economic, Social and Cultural Rights, GA res 2200A (XXI), 21 UN GAOR Supp (No 16) at 49, UN Doc A/6316 (1966), 993 UNTS 3, entered into force 3 January 1976 [hereinafter ICESCR], arts 2(2) and 3; International Convention on the Elimination of All Forms of Racial Discrimination, GA res 2106 (XX), Annex, 20 UN GAOR Supp (No 14) at 47, UN Doc A/6014 (1966), 660 UNTS 195, entered into force 4 January 1969 [hereinafter ICERD], art 1(1); CEDAW, above at note 15 at art 1; [European] Convention for the Protection of Human Rights and Fundamental Freedoms, 213 UNTS 222, entered into force 3 September 1953 [hereinafter ECHR] art 14; American Convention on Human Rights, OAS Treaty Series No 36, 1144 UNTS 123, entered into force 18 July 1978 [hereinafter AMCHR] art 1; African Charter on Human and Peoples' Rights, adopted 27 June 1981, OAU Doc CAB/LEG/67/3 rev 5, 21 ILM 58 (1982), entered into force 21 October 1986 [hereinafter ACHPR] art 2; Commonwealth of Independent States Convention on Human Rights and Fundamental Freedoms (CIS Convention) (1995), available at <http://hei.unige.ch/ clapham/hrdoc/docs/CIS\%20convention. doc >; art 20(2); League of Arab States, Revised Arab Charter on Human Rights, 22 May 2004, reprinted in (2005) 12 International Human Rights Reports 893, art 3.

26 ACHPR, above at note 25. For the analysis, see C Heyns "The African regional human rights system: the African Charter" (2004) 108 Penn State Law Review 679.

27 Adopted by the 2nd Ordinary Session of the Assembly of the African Union, Maputo, on 11 July 2003; reprinted in 1 African Human Rights Law Journal 40, entered into force 25 November 2005.

28 ACHPR arts 2, 3 and 18(3). 
However, the above provisions do not adequately address the human rights of women in Africa. For example, while article 18 prohibits discrimination against women, it does so only in the context of the family. In addition, explicit provisions guaranteeing the right of consent to marriage and equality of spouses during and after marriage are absent. These omissions are compounded by the fact that the Charter places emphasis on traditional African values and traditions without addressing concerns that many customary practices, such as female genital mutilation, forced marriage and wife inheritance, can be harmful or life threatening to women. According to article 18(2) of the Charter: "The State shall have the duty to assist the family which is the custodian of morals and traditional values recognised by the community". Under article 29(7), an individual has a duty "to preserve and strengthen positive African cultural values in his relations with other members of the society, in the spirit of tolerance, dialogue and consultation and, in general, to contribute to the promotion of the moral well being of society". By ignoring critical issues such as custom and marriage, it has been argued that the Charter inadequately protects women's human rights. ${ }^{29}$ It is against this background that, during its 23rd Session held in April 1998, the African Commission endorsed the appointment of the first Special Rapporteur on the Rights of Women in Africa (SRRWA) with a mandate that includes working towards the adoption and ratification of the Protocol to the African Charter on the Rights of Women in Africa. ${ }^{30}$

The scope of "positive African cultural values" is subject to debate. Beyani argues that article 29(7) cannot be interpreted as trumping the nondiscrimination provisions in the Charter. ${ }^{31}$ Taken in its totality as a human rights treaty, it is arguable that the "positive African cultural values" described in the Charter are those that are consonant with principles of equality and non-discrimination. In this respect, a "progressive and liberal construction of the Charter seems to leave no room for the discriminatory treatment of women". ${ }^{32}$ The adoption by the African Commission, in Legal Resources Foundation v Zambia, of the definition of discrimination drawn by the United Nations Human Rights Committee (HRC) in General Comment 18, which is itself based on CEDAW article 1 and CERD article 1, suggests that

29 M Wandia "Rights of women in Africa: launch of petition to the African Union" (June 2004), available at <http://www.choike.org/nuevo_eng/informes/1944.html> (accessed 26 July 2006).

30 ACHPR, Special Rapporteur on Women's Rights: Resolution and Mandate, available at: $<$ http://www.achpr.org/english/_info/index_women_en.html\#1 > (accessed 26 June 2006); F Banda "Blazing a trail: the African Protocol on Women's Rights comes into force” (2006) 50/1 Journal of African Law 72.

31 C Beyani "Toward a more effective guarantee of women's rights in the African human rights system" in R Cook (ed) Human Rights of Women: National and International Perspectives (1994, University of Pennsylvania Press) 285.

32 M Mutua "The African human rights system: a critical evaluation”, available at: < http:/| hdr.undp.org/docs/publications/background_papers/MUTUA.PDF $>$ at 9 (last accessed 14 November 2006). 
there can be no derogation of the equality principle, not even for culture. ${ }^{33}$ Finally, the African Commission guidelines to states on reporting, which encompass both public and private sphere violations, are based on CEDAW reporting guidelines. ${ }^{34}$

\section{Protocol to the African Charter on the Rights of Women in Africa}

The Protocol was adopted on 11 July 2003 during the Second Ordinary Heads of States and Governments Summit held in Maputo, Mozambique. It had taken eight years for the draft text of this critical new human rights instrument for African women to be adopted. On 25th November 2005, the Protocol came into force having received the required 15 ratifications. By February 2006, nearly three years after the adoption of the Protocol, only 17 (out of 53) African states had ratified the Protocol. ${ }^{35}$ The reluctance to ratify the Protocol is itself indicative of the state of women's human rights in Africa. However, human rights instruments in Africa have historically taken a long time to be ratified and enter into force due to the lack of political will. The ACHPR, adopted in 1981, only came into force five years later in 1986; the Protocol establishing the African Court on Human and Peoples' Rights $^{36}$ came into force in 2004, six years after its adoption in 1998; and the African Charter on the Rights and Welfare of the Child, ${ }^{37}$ which was adopted in 1990, took nine years to come into force.

The Protocol protects the civil and political rights of women, their economic, social and cultural rights and also their collective rights. ${ }^{38}$ Apart from re-emphasizing and extending UN instruments on human rights of women, the Protocol enshrines the mainstreaming of human rights and gender equality in African affairs, ${ }^{39}$ an objective and principle of the African Union (AU). ${ }^{40}$ The specific rights protected under the Protocol are, broadly, the rights to: non-discrimination (article 2); dignity (article 3); life,

33 See African Commission on Human and Peoples' Rights Legal Resources Foundation v Zambia Comm No 211/98, Decisions on Communications Brought before the African Commission, 29th Ordinary Session (Tripoli, May 2001) para 63; HRC General Comment 18, Non-discrimination (37th session, 1989) UN Doc HRI $\backslash$ GEN $\backslash 1 \backslash$ Rev1 (1994) at 26.

34 F Viljoen "State reporting under the African Charter on Human and Peoples' Rights: a boost from the South" (2000) 44/1 Journal of African Law 110.

35 These were Benin, Cape Verde, Comoros, Djibouti, Gambia, Libya, Lesotho, Mali, Malawi, Mozambique, Mauritania, Namibia, Nigeria, Rwanda, South Africa, Senegal and Togo.

369 June 1998, OAU Doc OAU/LEG/EXP/AFCHPR/PROT (III).

37 OAU Doc CAB/LEG/24.9/49 (1990), entered into force 29 November 1999.

38 See M Ssenyonjo "Protocol to the African Charter on Human and Peoples' Rights on the Rights of Women in Africa: introductory note" (2004) 11 International Human Rights Reports 859; M Baderin "Recent developments in the African regional human rights system" (2005) 5 Human Rights Law Review 117; Banda "Blazing a trail”, above at note 30.

39 VO Nmehielle "Development of the African human rights system in the last decade" (2004) 11(3) Human Rights Brief 6.

40 Constitutive Act of the African Union OAU Doc CAB/LEG/23.15, entered into force 26 May 2001, art 3(h) states: "The objectives of the Union shall be to: Promote and protect human and peoples' rights"; art 4(1)(1) provides: "The Union shall function in accordance with the following principles: Promotion of gender equality". 
integrity and security of the person (article 4); equal right in a marriage separation, divorce or annulment of marriage (articles 6-7); access to justice and equal protection before the law (article 8); participation in the political and decision-making process (article 9); peace (article 10); protection of women in armed conflicts (article 11); education and training (article 12); economic and social welfare rights (article 13); health and reproductive rights including a woman's right to have "medical abortion in cases of sexual assault, rape, incest, and where the continued pregnancy endangers the mental and physical health of the mother or the life of the mother or the foetus" (article 14); 41 food security (article 15); adequate housing (article $16)$; to live in a "positive cultural context" (article 17); a healthy and sustainable environment (article 18); sustainable development (article 19); widows' rights (article 20); inheritance (article 21); the special protection of elderly women (article 22), women with disabilities (article 23), and women in distress (article 24).

Article 26 of the Protocol states the obligations of the state parties in the following terms:

"1. States Parties shall ensure the implementation of this Protocol at national level, and in their periodic reports submitted in accordance with Article 62 of the African Charter, indicate the legislative and other measures undertaken for the full realisation of the rights herein recognised.

2. States Parties undertake to adopt all necessary measures and in particular shall provide budgetary and other resources for the full and effective implementation of the rights herein recognised".

In particular, article 5 of the Protocol obliges states parties to take all "necessary legislative" and "other measures" to eliminate harmful practices which negatively affect the human rights of women and which are contrary to recognized international standards, including:

"a. creation of public awareness in all sectors of society regarding harmful practices through information, formal and informal education and outreach programmes;

b. prohibition, through legislative measures backed by sanctions, of all forms of female genital mutilation, scarification, medicalisation and para-medicalisation of female genital mutilation and all other practices in order to eradicate them;

c. provision of necessary support to victims of harmful practices through basic services such as health services, legal and judicial support, emotional and psychological counselling as well as vocational training to make them self-supporting;

41 See also HRC Karen Noelia Llantoy Huamán v Peru Communication No 1153/2003, UN Doc CCPR/C/85/D/1153/2003 (2005). 
d. protection of women who are at risk of being subjected to harmful practices or all other forms of violence, abuse and intolerance".

Unlike some treaties (such as the Rome Statute of the International Criminal Court), ${ }^{42}$ it is noteworthy that the Protocol does not provide expressly that reservations or declarations are not permitted. While this position was adopted to secure wider ratification of the Protocol by African states who consider that they have difficulties in guaranteeing all the rights in the Protocol but can nonetheless accept the generality of obligations in that instrument, it is likely that states would make reservations similar to those made by various African states to CEDAW. ${ }^{43}$ For example, the reservations to CEDAW made by Egypt, Libyan Arab Jamahiriya, Mauritania and Morocco specifically referred to the traditional malecentred interpretations of Islamic law (shari'a) provisions. ${ }^{44}$ In particular, Egypt's reservation to article 16 of CEDAW, concerning the equality of men and women in all matters relating to marriage and family relations during the marriage and upon its dissolution, states:

"The provisions of the shari'a lay down that the husband shall pay bridal money to the wife and maintain her fully and shall also make a payment to her upon divorce, whereas the wife retains full rights over her property and is not obliged to spend anything on her keep. The shari'a therefore restricts the wife's rights to divorce by making it contingent on a judge's ruling, whereas no such restriction is laid down in the case of the husband". 45

The CEDAW Committee has urged states to expedite the steps necessary for the withdrawal of reservations incompatible with the object and purpose of the Convention. ${ }^{46}$ In particular, the Committee's view is that articles 2 and 16 of CEDAW are central to the object and purpose of the Convention and that, in accordance with article 28 , paragraph 2 , they should be withdrawn. ${ }^{47}$

42 UN Doc 2187 UNTS 90, entered into force 1 July 2002. Art 120 provides: "No reservations may be made to this Statute".

43 For specific reservations by state, see < http://www.un.org/womenwatch/daw/cedaw/ reservations-country.htm $>$ (last visited 17 July 2006).

44 Ibid. The primary sources of Islamic law are the Qur'an (a religious text considered by Muslims to be revealed by God) and Sunnah (reported sayings and practices of Prophet Muhammad, pbuh). Other secondary sources include ijma (consensus among Muslim jurists regarding questions of shari'a), Qiyas (drawing analogy from the essence of divine principles) and ijtihad (exercising of independent juristic reasoning). See S Ali Gender and Human Rights in Islam and International Law: Equal before Allah, Unequal before Man? (2000, Kluwer Law International) 19-23; A Khan "The reopening of the Islamic Code: the second era of Ijtihad" (2003) 1 University of St. Thomas Law Journal 341.

45 See note 43 above.

46 See the CEDAW Committee's statement on reservations in the report on the 19th session, Official Records of the General Assembly, Fifty-third Session, Supplement No. 38 (A/53/38/ Rev 1) part 2 at chap I.

47 CEDAW Concluding Observations: Egypt CEDAW A/56/38 (2001) at para 327. 
However, states have continued to observe these reservations in practice and thus violate human rights of women.

The absence of an explicit clause prohibiting reservations in the Protocol to the ACHPR does not safeguard against the state practice of entering such reservations. In accordance with article 19 of the Vienna Convention on the Law of Treaties, ${ }^{48}$ a state may, when signing, ratifying, accepting, approving or acceding to a treaty, formulate a reservation unless the reservation is prohibited by the treaty; the treaty provides that only specified reservations, which do not include the reservation in question, may be made; or where the reservation is incompatible with the object and purpose of the treaty. ${ }^{49}$ The implication is that if a treaty is silent on the issue of reservations, they are allowed although the absence of a prohibition on reservations does not mean that any reservation is permitted. With respect to the African Protocol on Women's Rights, it was suggested by the Southern African Development Community member states (SADC group) that reservations should be expressly prohibited, but this suggestion was not taken up..$^{50}$ In a "standard-setting" instrument, which articulates the human rights of women, each of the many articles, and indeed their interplay, secures the objectives of the Protocol. As stated in the preamble to the Protocol, the Protocol is intended "to ensure that the rights of women are promoted, realised and protected in order to enable them to enjoy fully all their human rights". Clearly then, the object and purpose of the Protocol is to create legally binding standards for women's human rights by defining certain civil, political, economic, social and cultural rights of women, and to place them in a framework of obligations which are legally binding for those states which ratify, and to provide an efficacious supervisory machinery for the obligations undertaken. ${ }^{51}$ The provisions in the Protocol that represent customary international law (and a fortiori when they have the character of peremptory norms) may not be the subject of reservations as such reservations would not be compatible with the object and purpose of the Protocol. ${ }^{52}$ For example, a reservation to the obligation to combat all forms of discrimination against women (article 2)

481155 UNTS 331, 8 ILM 679, entered into force 27 January 1980.

49 See A Aust Modern Treaty Law and Practice (2000, Cambridge University Press) at 108-12.

50 F Banda Women, Law and Human Rights: An African Perspective (2005, Hart Publishing) at 75-79.

51 See also HRC General Comment 24 (52), General Comment on Issues Relating to Reservations Made upon Ratification or Accession to the Covenant or the Optional Protocols thereto, or in Relation to Declarations under Article 41 of the Covenant UN Doc CCPR/C/21/Rev1/Add6 (1994), para 7.

52 Id at para 8, noting that under the ICCPR: “[A] State may not reserve the right to engage in slavery, to torture, to subject persons to cruel, inhuman or degrading treatment or punishment, to arbitrarily deprive persons of their lives, to arbitrarily arrest and detain persons, to deny freedom of thought, conscience and religion, to presume a person guilty unless he proves his innocence, to execute pregnant women or children, to permit the advocacy of national, racial or religious hatred, to deny to persons of marriageable age the right to marry, or to deny to minorities the right to enjoy their own culture, profess their own religion, or use their own language". 
would not be acceptable. Nor may a state reserve an entitlement not to take the necessary steps at the domestic level to give effect to the rights of the Protocol (article 26). ${ }^{53}$

\title{
The state of women's rights in Africa in practice
}

Every state in Africa is a party to at least one international treaty prohibiting discrimination on the basis of sex in the enjoyment of human rights or a party to an international treaty providing for the equal rights of men and women to the enjoyment of all human rights. Despite this, it is essential to note:

\begin{abstract}
"Women are often denied equal enjoyment of their human rights, in particular by virtue of the lesser status ascribed to them by tradition and custom, or as a result of overt or covert discrimination. Many women experience distinct forms of discrimination due to the intersection of sex with such factors as race, colour, language, religion, political and other opinion, national or social origin, property, birth, or other status, such as age, ethnicity, disability, marital, refugee or migrant status, resulting in compounded disadvantage". ${ }^{54}$
\end{abstract}

For example, persons with mental disabilities are often subjected to human rights abuses including: rape and sexual abuse; forced sterilizations; being chained to soiled beds for long periods of time, and, in some cases being held inside cages; violence and torture; the administration of treatment without informed consent; grossly inadequate sanitation; and a lack of food. ${ }^{55}$ However, women with mental disabilities are especially vulnerable to forced sterilization and sexual violence, a violation of their sexual and reproductive health rights. ${ }^{56}$ Moreover, women with disabilities belonging to ethnic and racial minorities often experience compounded disadvantage due to the intersection of sex with ethnicity and race although this has been historically neglected..$^{57}$ This is because "[c]ertain forms of racial discrimination may be directed towards women specifically because of their gender, such as sexual violence committed against women members of particular racial or ethnic groups in detention or during armed conflict; the coerced

53 Id at para 9.

54 CESCR General Comment No. 16 E/C12/2005/4 (2005) at para 5.

55 P Hunt Report of the Special Rapporteur on the Right of Everyone to the Enjoyment of the Highest Attainable Standard of Physical and Mental Health E/CN 4/2005/51 (11 February 2005) at para 9.

56 Id at para 12; KL Raye Women's Rights Advocacy Initiative: Violence, Women, and Mental Disability (1999, Mental Disability Rights International); L Dowse and C Frohmader Moving Forward: Sterilization and Reproductive Health of Women and Girls with Disabilities (2001, Women with Disabilities, Australia).

57 CESCR General Comment No. 5, Persons with Disabilities (11th session, 1994) UN Doc E/1995/ 22 at 19 (1995) at para 19 stating: "Persons with disabilities are sometimes treated as genderless human beings. As a result, the double discrimination suffered by women with disabilities is often neglected". 
sterilization of indigenous women; abuse of women workers in the informal sector or domestic workers employed abroad by their employers". 58

In Libya, for example, there are "numerous reports about the existence of racial prejudices against Black Africans, which on some occasions has led to acts of violence against them". ${ }^{59}$ Women have been the worst victims since the human rights of women are often subordinated to rigid social norms condoned and reinforced by the Libyan government. ${ }^{60}$ Consequently, there are circumstances in which discrimination (on grounds of disability or race) only or primarily affects women, or affects women in a different way, or to a different degree than men. For example, women often have less access to education and healthcare than men which compromises their opportunities for employment and advancement. ${ }^{61}$ In Botswana, women "refugees have access neither to the Anti Retroviral (ARV) Therapy Programme nor the Prevention of Mother-to-Child Transmission of [the] HIV Programme". ${ }^{62}$ Therefore, despite the ratification of human rights instruments by the majority of African states, women in Africa still continue to be "victims of discrimination and harmful practices" which violate their human rights. ${ }^{63}$ One of the key obstacles to the realization of women's human rights in Africa is deeply-rooted in culture.

\section{PREJUDICIAL CULTURAL PRACTICES AND CUSTOMS AS AN OBSTACLE TO THE REALIZATION OF WOMEN'S HUMAN RIGHTS IN AFRICA}

\section{African culture in general}

Anthropologists commonly use the term "culture" to refer to a society or group in which many people live and think in the same ways. ${ }^{64}$ Culture includes "inherited ideas, beliefs, values, and knowledge, which constitute the shared bases of social action".65 In this respect, culture is a macroconcept, which subsumes religion as an aspect of culture. ${ }^{66}$

Although a number of African states have ratified treaties which guarantee the equality of men and women and have incorporated the

58 CERD General Recommendation No. 25: Gender Related Dimensions of Racial Discrimination: 20/ 03/2000, A/55/18, Annex V at para 2.

59 CESCR Concluding Observations: Libyan Arab Jamahiriya E/C12/LYB/CO/2 (25 January 2006) at para 12.

60 Human Rights Watch Libya: A Threat to Society? Arbitrary Detention of Women and Girls for "Social Rehabilitation" (February 2006) Vol 18, No 2(E), available at: < http://hrw.org/ reports/2006/libya0206/>.

61 CESCR General comment No. 18: The Right to Work E/C12/GC/18 (6 February 2006) at para 13.

62 CERD Concluding Observations: Botswana CERD/C/BWA/CO/16 (4 April 2006) at para 19.

63 African Women's Rights Protocol, preamble at para 12.

64 F Raday, "Culture, religion, and gender" (2004) 1/4 International Journal of Constitutional Law 663 at 665-66.

65 See Collins English Dictionary (1999, HarperCollins Publishers) at 385.

66 Raday "Culture, religion and gender", above at note 64 at 665 . 
principles of equality and non-discrimination into national constitutions, the persistence of deep-rooted adverse patriarchal attitudes and firmly entrenched stereotypical behaviour with respect to the role of women and men in the family and society limit the full implementation of the human rights of women. ${ }^{67}$ The widespread and continuing existence of harmful traditional practices in African states affect the equal right of men and women to the enjoyment of all human rights. ${ }^{68}$ While it is acknowledged that culture (as reflected in customary law in Africa) in some cases can protect some of women's human rights, the prevalence in Africa of certain harmful traditions, customs and cultural practices leads to substantial discrimination against women thereby preventing them from fully exercising their human rights. ${ }^{69}$ Although "everyone" has a right to cultural participation, ${ }^{70}$ including cultural rights of specific groups, ${ }^{71}$ African cultures and traditions as they presently exist are mainly made for and by men! ${ }^{22}$ In Eritrea, for example, while participation in the National Service creates eligibility for access to land and other economic resources, women are exempt from the National Service on grounds of marriage, thus losing eligibility for access to land and other resources. ${ }^{73}$ This perpetuates women's subordination in the family and society and constitutes serious obstacles to women's enjoyment of their human rights.

Some of these cultures are enforced through (criminal) legislation. In Nigeria, for example, the Penal Code permits husbands to use physical

67 See, eg, CEDAW Concluding Observations: Mali CEDAW/C/MLI/CO/5 (3 February 2006) at para 17; Egypt A/56/38 (2 February 2001) at para 325; Cameroon A/55/38 (26 June 2000) at paras 53-54; Democratic Republic of Congo A/55/38 (1 February 2000) at paras 230-32; Guinea A/56/38 (31 July 2001) at paras 122 and 138; United Republic of Tanzania A/53/38/ Rev1 (6 July 1998) at paras 229-30.

68 See, eg, CESCR Concluding Observations: Zambia E/C12/1/Add106 (23 June 2005) at para 10, noting that "the persistence of customs and traditions harmful to women" is one of the factors impeding the implementation of the ICESCR.

69 Id at paras 14, 23 and 32. In para 23, the CESCR was "concerned about the harsh living conditions of widows and girl orphans due to, among other things, harmful traditional practices such as 'widow-cleansing', early marriages and denial of inheritance". Similarly, para 32 the CESCR noted that in Zambia "traditional attitudes [against girl education] continue and that discrimination against girl children is prevalent in the State party". See also Raday "Culture, religion and gender", above at note 64 at $663-715$.

70 See ICESCR art 15(1)(a); UDHR art 27(1) stating: "Everyone has the right freely to participate in the cultural life of the community"; CERD art 5(e) (vi); the Additional Protocol to the American Convention on Human Rights in the Area of Economic, Social and Cultural Rights (Protocol of San Salvador) art 14; and ACHPR art 17(2).

71 See ICCPR art 27; CEDAW art 13 (c); the Convention on the Rights of the Child (CRC) GA res 44/25, annex, 44 UN GAOR Supp (No 49) at 167, UN Doc A/44/49 (1989), entered into force 2 September 1990, art 31 and the International Convention on the Rights of All Migrant Workers and Members of their Families GA res 45/158 of 18 December 1990, entered into force 1 July 2003, art 31.

72 J Oloka-Onyango “Who's watching 'Big Brother'? Globalization and the protection of cultural rights in present day Africa” 2005 (4) Human Rights Quarterly 1245 at 1268.

73 CEDAW Concluding Observations: Eritrea CEDAW/C/ERI/CO/3 (3 February 2006) at para 14. 
means to chastise their wives as long as it does not result in "grievous harm", which is defined as loss of sight, hearing, power of speech, facial disfigurement or life-threatening injuries. ${ }^{74}$ In more traditional areas of Nigeria, the courts and police have been reluctant to intervene to protect women who have formally accused their husbands of abuse if the level of alleged abuse did not exceed the customary norms of those areas. ${ }^{75}$ This denies women in Africa "the right to live in a positive cultural context and to participate at all levels in the determination of cultural policies" affecting their lives. ${ }^{76}$ The right of everyone to cultural participation seeks to encourage the active contribution of all members of society to the progress of society as a whole. As such, it is intrinsically linked to, and is dependent on the enjoyment of, other human rights such as the right to own property alone as well as in association with others, ${ }^{77}$ the freedom of expression including the freedom to seek, receive and impart information and ideas of all kinds, ${ }^{78}$ the right to the full development of the human personality ${ }^{79}$ and freedom of movement. ${ }^{80}$

Women are often denied travel documents just because they are female they are subjected to legal or de facto requirements which prevent them from travelling, such as the requirement of consent of a third party to the issuance of a passport or other type of travel documents to an adult woman. One case from Libya demonstrates the effect of violations of women's freedom of movement on women's enjoyment of other human rights. In Loubna El Ghar v Libyan Arab Jamahiriya, ${ }^{81}$ the author, of Libyan nationality, had lived all her life in Morocco with her divorced mother and held a residence permit for that country. As a student of French law at the Hassan II University in Casablanca, she wished to continue her studies in France and to specialize in international law. To that end, she applied to the Libyan Consulate in Morocco for a passport beginning in 1998. In 2002, the Libyan consul indicated to the author that it was not possible to issue her a

74 US Department of State Country Reports on Human Rights Practices - 2005, Nigeria (8 March 2006, released by the Bureau of Democracy, Human Rights, and Labor, available at $<$ http://www.state.gov/g/drl/rls/hrrpt/2005/61586.htm > (accessed 18 March 2006). In $2003,64.5 \%$ of women and $61.3 \%$ of men agreed that a husband was justified in hitting or beating his wife for at least 1 of 6 specified reasons, including "burning food and not cooking on time", see National Population Commission Nigeria Demographic and Health Survey (2003, National Population Commission and ORC Macro), available at: <http:// www.measuredhs.com/pubs/pdf/FR148/00FrontMatter.pdf $>$.

75 US Department of State Country Reports, above at note 74.

76 African Women's Rights Protocol art 17(1).

77 See UDHR art 17; ICERD art 5 (d) (v); Protocol No 1 to the Convention for the Protection of Human Rights and Fundamental Freedoms (European Convention on Human Rights - ECHR) art 1; the American Convention on Human Rights art 21; and ACHPR art 4.

78 See UDHR art 19; ICCPR art 19(2); ECHR art 5; the American Declaration on Human Rights art 13 and ACHPR art 9.

79 See UDHR art 26(2); ICESCR art 13(1).

80 ICCPR art 12(2) provides: "Everyone shall be free to leave any country, including his own".

81 HRC Communication No. 1107/2002 (15 November 2004) CCPR/C/82/D/1107/2002. 
passport but that she could be given a laissez-passer (travel document) for Libya, by virtue of a "regulation" that was explained neither orally nor on the laissez-passer itself. The passport application submitted to the Libyan Consulate was thus rejected without any explanation of the grounds for the decision, the only comment being that since the author "is a native of Morocco and has not obtained a passport, this travel document [laissez-passer] is issued to enable her to return to national territory". The Human Rights Committee (HRC) considered that "this laissez-passer cannot be considered a satisfactory substitute for a valid Libyan passport that would enable the author to travel abroad". ${ }^{82}$ The Committee concluded that "the facts before it disclose a violation of article 12, paragraph 2, of the Covenant (ICCPR) insofar as the author was denied a passport without any valid justification and subjected to an unreasonable delay, and as a result was prevented from travelling abroad to continue her studies". 83 The Committee urged "the State party to issue the author with a passport without further delay" and to "take effective measures to ensure that similar violations do not recur in future". ${ }^{84}$ It is clear that the refusal to issue a passport to a female student on the basis of an "unwritten regulation" (ie apparently because the applicant was female and she had no consent from a third party - her father) in this case not only violated her freedom of movement (a civil and political right), but also prevented her from travelling abroad for further studies (a violation of the right to education - an economic, social and cultural right). ${ }^{85}$

It is, therefore, not surprising that many features of customary law in Africa effectively operate "against the dignity, welfare or interests of women (and) undermine their status". ${ }^{86}$ Generally, it has been noted that:

"Traditional cultural practices reflect values and beliefs held by members of a community for periods often spanning generations. Every social grouping in the world has specific traditional cultural practices and beliefs, some of which are beneficial to all members, while others are harmful to a specific group, such as women. These harmful traditional practices include female genital mutilation (FGM); forced feeding of women; early marriage; the various taboos or practices which prevent women from controlling their

82 Id at para 7.2 .

83 Id at para 8.

84 Id at para 9.

85 See also LE Chamblee "Rhetoric or rights?: When culture and religion bar girls' right to education" (2004) 44 Virginia Journal of International Law 1073.

86 Oloka-Onyango “Who's watching 'Big Brother'?", above at 72 at 1268, citing The Constition of the Republic of Uganda (1995) arts 33(6) and 32(1); and cultural objective no xxiv in the Preamble, which encourages the incorporation into aspects of Ugandan life of all cultures and customary values consistent with fundamental rights and freedoms and human dignity. 
own fertility; nutritional taboos and traditional birth practices; son preference and its implications for the status of the girl child; female infanticide; early pregnancy; and dowry price". 87

In the African context, harmful traditional practices include "the practice of female genital mutilation $[\mathrm{FGM}],{ }^{88}$ as well as scarification and ritual killing of children", 89 corporal punishment (in the family, schools and other institutions), ${ }^{90}$ the acceptance of domestic violence towards women, ${ }^{91}$ forced and/or early marriages, ${ }^{92}$ polygamy (more specifically, polygyny), and the denial of inheritance rights to women. ${ }^{93}$ Many customary laws discriminate against women in the areas of inheritance, marriage and

87 UNHCHR Harmful Traditional Practices Affecting the Health of Women and Children Fact Sheet No 23 (1995), available at: <http://www.unhchr.ch/html/menu6/2/fs23.htm\#I>.

88 K Bowman "Comment: bridging the gap in the hopes of ending female genital cutting” (2005) III/I Santa Clara Journal of International Law 132; N Mendelsohn "At the crossroads: the case for and against a cultural defense to female genital mutilaton" (2004) 56 Rutgers Law Review 1011; CESCR Concluding Observations: Egypt E/C.12/1/Add 44 (23 May 2000) at para 16: "The Committee further notes with concern that the percentage of women who are victims of FGM remains alarmingly high: WHO statistics for 1995 showed an estimated 97 per cent prevalence of FGM ('Female Genital Mutilation: An Overview', WHO, Geneva, 1998, p. 13)”; CEDAW Concluding Observations: Eritrea CEDAW/C/ERI/CO/3 (3 February 2006) at para 18, stating that "the Committee is concerned at the high incidence of female genital mutilation in the country and the State party's reluctance to expedite the adoption of legislation aimed at eradicating this practice". In respect of Uganda, the CRC expressed its concern in 2005 that "FGM is not specifically prohibited by law and is still widely practised in the State party": see CRC Concluding Observations: Uganda CRC/C/UGA/CO/2 (23 November 2005) at para 55.

89 Committee on the Rights of the Child (CRC) Concluding Observations: Nigeria CRC/C/15/Add 257 (13 April 2005) at para 56.

90 In Nigeria, eg, the shari'a legal code to children prescribes "penalties and corporal punishment such as flogging, whipping, stoning and amputation, which are sometimes applied to children": see id at para 38(d). See also CRC Concluding Observations: Uganda CRC/C/UGA/CO/2 (23 November 2005) at para 39, noting that: "While taking note that corporal punishment has been prohibited in schools by a circular of the Ministry of Education, and in the penal system under the Children's Act, the Committee remains concerned that corporal punishment is still traditionally accepted and widely practised in the family and in other settings"; G Muhwezi “Teacher's canes paralyse student" (30 July 2006) Sunday Monitor; and Global Initiative to End All Corporal Punishment of Children Lawfulness of Corporal Punishment: Uganda (May 2006), available at: <http://www.endcorporalpunishment.org/pages/progress/ reports/uganda.html $>$.

91 CRC Concluding Observations: Nigeria, above at note 89 at para 44. See also CG Bowman "Theories of domestic violence in the African context" (2003) 11 American University Journal of Gender, Social Policy and the Law 847.

92 CRC Concluding Observations: Nigeria, above at note 89 at para 54 .

93 See, eg, The Centre on Housing Rights and Evictions (COHRE) Bringing Equality Home: Promoting and Protecting the Inheritance Rights of Women - A Survey of Law and Practice in Sub-Saharan Africa (2004, COHRE); CESCR Concluding Observations: Senegal E/C.12/1/Add 62 (24 September 2001) at para 15, noting that discriminatory practices against women and girls in Senegal include "polygamy, restricted access to land, property, housing and credit facilities, and the inability to inherit land". 
divorce. ${ }^{94}$ These areas are, therefore, key to a deeper understanding of why women in Africa do not enjoy their rights. Yet some states have only shown limited efforts to address such discriminatory cultural practices and stereotypes directly and maintain that "women themselves are primarily responsible for changing their position of disadvantage". ${ }^{95}$ The next section discusses random cases of violations of women's rights in Africa, focusing especially on (some) traditional customs in areas of polygyny and divorce.

\section{Polygamous marriages}

Some traditional practices in Africa are so firmly established that while they are, from an international human rights perspective, generally considered as contrary to women's equality with men, they are recognized even in the African Women's Rights Protocol. One of the clearest examples is polygamy, ${ }^{96}$ which, according to the Human Rights Committee (HRC), discriminates against women and violates their dignity:

"It should also be noted that equality of treatment with regard to the right to marry implies that polygamy is incompatible with this principle. Polygamy violates the dignity of women. It is an inadmissible discrimination against women. Consequently, it should be definitely abolished wherever it continues to exist". 97

Although the African Women's Right Protocol prohibits discrimination against women and guarantees women's right to dignity, ${ }^{98}$ it recognizes polygamy. Article 2(1) of the Protocol recognizes that "States Parties shall combat all forms of discrimination against women through appropriate legislative, institutional and other measures", and under article 2(2),

"States Parties shall commit themselves to modify the social and cultural patterns of conduct of women and men through public education,

94 See, eg, PO Davies "Marriage, divorce, and inheritance laws in Sierra Leone and their discriminatory effects on women" (2005) 12/3 Human Rights Brief 17; B Oppermann "The impact of legal pluralism on women's status: an examination of marriage laws in Egypt, South Africa, and the United States" (2006) 17 Hastings Women's Law Journal 65.

95 CEDAW Concluding Observations: Togo CEDAW/C/TGO/CO/3 (3 February 2006) at para 14.

96 In this article, polygamy has been used to mean polygyny, meaning having two or more wives.

97 HRC General Comment No. 28, Equality of Rights Between Men and Women (Article 3) UN Doc CCPR/C/21/Rev1/Add 10 (2000) at para 24. See also HRC Concluding Observations: Algeria UN Doc CCPR/C/79/Add95 (1998) at para 13; id Cameroon UN Doc CCPR/C/79/Add 116 (1999)at para 10; id Gambia UN Doc CCPR/CO/75/GMB (2004) at para 18; id Libyan Arab Jamahiriya UN Doc CCPR/C/79/Add 101 (1998) at para 17; id Nigeria UN Doc CCPR/C/79/Add 65 (1996) at para 25; id Senegal UN Doc CCPR/C/79/Add 82 (1997) at para 12.

98 African Women's Rights Protocol art 3(1): "Every woman shall have the right to dignity inherent in a human being and to the recognition and protection of her human and legal rights". 
information, education and communication strategies, with a view to achieving the elimination of harmful cultural and traditional practices and all other practices which are based on the idea of the inferiority or the superiority of either of the sexes, or on stereotyped roles for women and men".

More specifically, under article 5, "States Parties shall prohibit and condemn all forms of harmful practices which negatively affect the human rights of women and which are contrary to recognized international standards". One would have expected such prohibited harmful cultural and traditional practices to include polygamy. Nevertheless, with respect to polygamy, the Protocol simply states in article 6(c):

"States Parties shall ensure that women and men enjoy equal rights and are regarded as equal partners in marriage. They shall enact appropriate national legislative measures to guarantee that: monogamy is encouraged as the preferred form of marriage and that the rights of women in marriage and family, including in polygamous marital relationships are promoted and protected".

This might be seen as being consistent with the ACHPR, which makes it a "duty" of the state and the individual to promote and protect the morals and "traditional/cultural values" recognized by the community. ${ }^{99}$ Clearly then, African states parties to the Protocol are only obliged to "encourage" monogamy. This is a weaker obligation since, in its ordinary and natural meaning, the obligation to "encourage" only extends to "inspire with the courage or confidence". ${ }^{100}$ The obligation is not to eliminate polygamy immediately. During the drafting of the African Women's Protocol, there was a vigorous debate on whether polygyny should be abolished. While non-governmental organizations demanded its abolition, government experts actively resisted its abolition because "Shari'a and many customary personal law systems recognized the rights of men to marry more than one wife" and that its abolition would result in "hardship being suffered by women already in polygynous unions". 101 It is recognized under the Protocol that it is possible to "promote" and "respect" women's rights in polygamous marital relationships, although it is less clear as to how this can be achieved in practice. By implication, therefore, polygamy under the Protocol is not seen as one of those practices which violate the dignity of women or as inadmissible discrimination against women (at least in the short-term).

99 ACHPR art 17(2): “The State shall have the duty to assist the family which is the custodian of morals and traditional values recognised by the community". See also ACHPR art 29(7).

100 See Collins English Dictionary (1999, HarperCollins Publishers) at 510.

101 Banda "Blazing a Trail", above at note 30 at 77. 
Given the fact that polygyny in Africa is deeply entrenched, it is considered to be very difficult to ban it outright, and if it was banned it might cause harm to the many women living in these relationships, whose only protection at the moment might be provisions of the impugned customary law. Therefore, it was seen as a necessary compromise measure, reflecting the realities of the situation in Africa and the difficulties involved in agreeing to a regional human rights treaty on women's human rights. This is especially the case given the fact that some states in Africa (for example, Egypt and Sudan) apply aspects of shari'a law interpreted by some scholars as permitting a man to marry up to four women. ${ }^{102}$ Such interpretation of the Quran has been contested on the basis that the Quran "never discriminates on the basis of gender. It is the interpretation of the Quran, reflecting masculine and patriarchal prejudices of the interpreters, that is discriminatory". ${ }^{103}$ The recognition of polygamy is difficult to reconcile with the above view of the HRC and the following view of the UN Committee on the Elimination of Discrimination against Women:

\begin{abstract}
"Polygamous marriage contravenes a woman's right to equality with men, and can have such serious emotional and financial consequences for her and her dependants that such marriages ought to be discouraged and prohibited. The Committee notes with concern that some states parties, whose constitutions guarantee equal rights, permit polygamous marriage in accordance with personal or customary law. This violates the constitutional rights of women, and breaches the provisions of article 5 (a) of the Convention". 104
\end{abstract}

Article 5(a) of the CEDAW, ${ }^{105}$ ratified by several African states and which is substantially similar to article 2(2) of the African Women's Rights Protocol, provides:

"States Parties shall take all appropriate measures: To modify the social and cultural patterns of conduct of men and women, with a view to achieving the elimination of prejudices and customary and all other practices which

102 A Mashhour "Islamic law and gender equality - could there be a common ground?: a study of divorce and polygamy in sharia law and contemporary legislation in Tunisia and Egypt" (2005) 27 Human Rights Quarterly 562; J Allain and A O'Shea "African disunity: comparing human rights law and practice of north and south African states" (2002) 24 Human Rights Quarterly 86; W Amien “Overcoming the conflict between the right to freedom of religion and women's rights to equality: a South African case study of muslim marriages" (2006) 28 Human Rights Quarterly 729.

103 N Shah "Women's human rights in the Koran: an interpretive approach" (2006) 28/4 Human Rights Quarterly 868 at 903.

104 CEDAW General Recommendation 21, Equality in Marriage and Family Relations (13th session, 1992) UN Doc A/49/38 at 1 (1994) at para 14.

105 GA res 34/180, 34 UN GAOR Supp (No 46) at 193, UN Doc A/34/46, entered into force 3 September 1981. 
are based on the idea of the inferiority or the superiority of either of the sexes or on stereotyped roles for men and women".

Since polygamy violates CEDAW article 5(a), it is submitted that the African Court on Human and Peoples' Rights (the Court), which under article 27 of the African Women's Rights Protocol is "seized with matters of interpretation arising from the application or implementation of this [Women's Rights] Protocol",106 should similarly interpret polygamy as violating article 2(2) of the Protocol. This would generally be consistent with the view that the "Court shall apply the provision of the Charter and any other relevant human rights instruments ratified by the States concerned"107 without prejudice to "more favourable provisions for the realisation of the rights of women contained in the national legislation of States Parties or in any other regional, continental or international conventions". ${ }^{108}$ As noted above, under article 60 of the African Charter, the African Commission on Human and Peoples' Rights (African Commission) and arguably the Court, since it complements the protective mandate of the African Commission, ${ }^{109}$ are required to draw inspiration from international law on human rights instruments ratified by African states. Such instruments, undoubtedly, include the Convention on the Elimination of All Forms of Discrimination against Women.

It follows, therefore, that under this approach, the obligation to "encourage" must be read in the light of the overall objective, indeed the raison d'etre, of the Protocol, which is to establish clear human rights obligations for states parties in respect of the full realization of the human rights of women. The increasingly high standard being required in the area of human rights protection correspondingly and inevitably requires greater firmness in assessing breaches of equality and non-discrimination as the fundamental values of democratic societies. Therefore, the Court should regard the Protocol as a "living instrument which must be interpreted in the light of present-day conditions". ${ }^{110}$ As noted above, this is "to ensure that the rights of women are promoted, realised and protected in

106 The first judges of the African Court on Human and Peoples' Rights were elected on 22 January 2006 at the Eighth Ordinary Session of the Executive Council of the African Union, held in Khartoum, Sudan. These are: Fatsah Ouguergouz (Algeria); Jean Emile Somda (Burkina Faso); Gerard Niyungeko (Burundi); Sophia AB Akuffo (Ghana); Kellelo Justina Masafo-Guni (Lesotho); Hamdi Faraj Fanoush (Libya); Modibo Tounty Guindo (Mali); Jean Mutsinzi (Rwanda); El Hadji Guissé (Senegal); Bernard Ngoepe (South Africa); and George W Kanyeihamba (Uganda).

107 Protocol to the African Charter on Human and Peoples' Rights on the Establishment of an African Court on Human and Peoples' Rights, 9 June 1998, OAU Doc OAU/LEG/ EXP/AFCHPR/PROT (III) art 6.

108 African Women's Right Protocol art 31.

109 Protocol to the African Charter on Human and Peoples' Rights on the Establishment of an African Court on Human and Peoples' Rights art 2.

110 A similar approach has been used by the European Court of Human Rights in interpreting the ECHR. See, eg, Selmouni v France Appl 25803/94, judgment of 28 July 1999 (2000) 29 EHRR 403 at para 101. 
order to enable them to enjoy fully all their human rights". ${ }^{111}$ Three specific obligations arise here - protect, promote and realize.

The obligation to protect requires states parties to take steps aimed directly at the elimination of prejudices, customary and all other practices that perpetuate the notion of inferiority or superiority of either of the sexes, and stereotyped roles for men and women. ${ }^{112}$ The obligation of states parties to protect under the Protocol includes, inter alia, the respect and adoption of constitutional and legislative provisions on the equal right of men and women to enjoy all human rights and the prohibition of discrimination of any kind; the adoption of legislation to eliminate discrimination and to prevent third parties or private actors (individuals, groups, corporations and other entities as well as agents acting under their authority) from interfering directly or indirectly with the enjoyment of women's human rights; ${ }^{113}$ the adoption of administrative measures and programmes, as well as the establishment of public institutions, agencies and programmes, to protect women against discrimination. ${ }^{114}$

States parties have an obligation to monitor and regulate the conduct of non-state actors (NSAs) to ensure that they do not violate the equal right of men and women to enjoy civil, political, economic, social and cultural rights. ${ }^{115}$ This obligation applies, for example, in cases where public services have been partially or fully privatized, ${ }^{116}$ or where armed rebels such as the notorious Lord's Resistance Army in Uganda - violate human rights including subjecting women to rape or sexual slavery. ${ }^{117}$

111 African Women's Right Protocol preamble at para 14 (emphasis added).

112 CESCR General Comment No. 16, above at note 54 at para 19.

113 See The Social and Economic Rights Action Center \& the Center for Economic and Social Rights/ Nigeria Communication 155/96 at para 44; Union des Jeunes Avocats $\mathrm{v}$ Chad Communication 74/92 (ACmHPR); $X$ and $Y$ v Netherlands 91 ECHR (1985) (Ser A) at 32 (ECtHR); Velasquez Rodriguez v Honduras judgment of 19 July 1988, Series C, No 4 (IACtHR) holding that a state has a positive duty to prevent human rights violations occurring in the territory subject to its effective control, even if such violations are carried out by third parties.

114 CESCR General Comment No. 16, above at note 54 at para 19; African Women's Rights Protocol art 2.

115 CESCR General Comment No. 16, above at note 54 at para 20; M. Sssenyonjo "Non-State Actors and Economic, Social and Cultural Rights" in M Baderin and R McCorquodale (eds.), Economic, Social and Cultural Rights in Action (2007, Oxford University Press) chap 6.

116 Ibid. See also, generally, K de Feyter and F Gomez (eds) Privatization and Human Rights in the Age of Globalization (2005, Intersentia).

117 M Ssenyonjo "Accountability of non-state actors in Uganda for war crimes and human rights violations" (2005) 10/3 Journal of Conflict and Security Law 405. The International Criminal Court (ICC) publicly unsealed warrants of arrest against the 5 LRA commanders (Joseph Kony, Vincent Otti, Okot Odhiambo, Raska Lukwiya and Dominic Ongwen) on 13 October 2005 and transmitted them to the governments of Uganda, Sudan and the Democratic Republic of the Congo. At the time of writing, these individuals were still wanted for trial at the ICC for multiple counts of "crimes against humanity and war crimes, including murder, abduction, sexual crimes, rape and child conscription". See ICC "Interpol issues first ICC Red Notices” (1 June 2006), available at: <http://www.icc-cpi.int/press/pressreleases/151.html>. 
The obligation equally applies where NSAs formulate policies that discriminate against women. A 1992 case from Zambia illustrates this point. ${ }^{118}$ This case involved challenging a NSA - the Intercontinental Hotel - which had a policy of refusing women entry, unless they were accompanied by a male escort. The hotel justified the policy as a necessary measure against prostitution. A security guard stopped a woman (Longwe) when she tried to retrieve her children from a party at the hotel. On another occasion, the same hotel refused Longwe admittance when she had arranged to meet a group of women activists in the hotel's bar. Longwe claimed at the Zambian High Court that the hotel's actions violated her right to freedom from discrimination under both Zambia's Constitution and under articles 1, 2 and 3 of CEDAW. The High Court noted that Zambia, being a party to international treaties such as the ACHPR and CEDAW, must respect and conform to the notion of gender equality. Reading international instruments and the Zambian Constitution in conjunction, the Court held that discriminating acts on the basis of gender carried out by NSAs violated the plaintiff's fundamental equality rights and women's rights. This case is notable because it applied human rights obligations to NSAs. The implication is that states must put an end to discriminatory actions "both in the public and the private sector". ${ }^{119}$ In particular, states should implement laws and policies to ensure that "pregnancies must not constitute an obstacle to employment and should not constitute justification for loss of employment". ${ }^{120}$

The obligation to promote and realize (fulfil) requires states parties to take steps to ensure that, in practice, men and women enjoy their civil, political, economic, social and cultural rights on a basis of equality. Such steps should include, but are not limited to, the following. ${ }^{121}$

First, the availability and accessibility of appropriate remedies, such as compensation, reparation, restitution, rehabilitation, guarantees of nonrepetition, declarations, public apologies, educational programmes, prevention programmes, revised policies, benchmarks and implementation programmes. ${ }^{122}$ Domestic courts must not shy away from confronting discriminatory customary practices against women. ${ }^{123}$ A decision of the

118 Sara H. Longwe v Intercontinental Hotels 1992/HP/765 (1993) 4 LRC 221 (High Court of Zambia). For the discussion, see T Kankasa-Mabula "The enforcement of human rights of Zambian women: Sara Longwe v Intercontinental Hotel revisited" (1989-1992) 2124 Zambia Law Journal 30.

119 HRC General Comment No. 28, above at note 97 at para 4.

120 CESCR General Comment No. 18: The Right to Work E/C.12/GC/18 (6 February 2006) at para 13.

121 CESCR General Comment No. 16, above at note 54 at para 21.

122 Montreal Principles, above at note 22 at para 36; African Women's Rights Protocol art 25. See also, generally, D Shelton Remedies in International Human Rights Law (2nd ed, 2005, Oxford University Press).

123 See Bhe and Others v Magistrate Khayelitsha and Others CCT 49/03, 2004 (2) SA 544 (C) (2004 (1) BCLR 27; Shibi v Sithole and Others CCT 69/03 (Shibi case); South African Human Rights Commission and Another v President of the Republic of South Africa and Another CCT 50/03 (15 October 2004), available at: <http://www.mangaung.co.za/LegalServices/Documents/ Shibi\%20Case.PDF $>$ (last accessed 6 March 2006). 
Nigerian Court of Appeal, affirmed by the Supreme Court, shows how domestic courts can enforce the human rights of women. ${ }^{124}$ This case involved a challenge of a local custom in Nigeria known as "Nrachi" or "Idegbe". ${ }^{125}$ This custom involves the performance of a ceremony whereby a man could keep one of his daughters perpetually in his home unmarried in order to care for the children, especially males, to succeed him (and thereby perform "women's traditional role"). Relying upon CEDAW article 2, the Nigerian Court of Appeal found the custom to be discriminatory on the basis of sex and in violation of the right to marry and women's equality rights. The Court stressed the importance of eliminating discriminatory customary practices in order to give international human rights practical effect. In holding that a female child can inherit from her deceased father's estate without the nrachi ceremony being performed, the Court observed:

\begin{abstract}
"In view of the fact that Nigeria is a party to the Convention [CEDAW], courts of law should give or provide teeth to its provisions. That is one major way of ameliorating the unfortunate situation Virginia found herself in, a situation where she was forced to rely on an uncouth custom not only against the laws of Nigeria but also against nature".'126
\end{abstract}

Secondly, the establishment and maintenance by states parties of appropriate effective venues for redress against human rights violations, including violations against women's ESCR. Such venues include independent courts and tribunals, administrative mechanisms, and national human rights and women's commissions that are accessible to all on the basis of equality, including the poorest and most disadvantaged and marginalized women.

Thirdly, the design and implementation of policies and programmes to give long-term effect to the civil, political, economic, social and cultural rights of both men and women on the basis of equality. These may include the adoption of temporary special measures to accelerate women's equal enjoyment of their rights, gender audits, and gender-specific allocation of resources. ${ }^{127}$

Finally, the promotion of equal representation of men and women in public office and decision-making bodies, and the promotion of the participation of men and women in development planning, decision-making

124 Muojekwu v Ejikeme [2000] 5 Nigerian Weekly Law Reports 657 at 402.

125 This situation usually arises when a deceased man leaves an estate, but no surviving male issue to inherit it. The idea underlying this practice is to save the lineage "from extinction". The daughter, now considered an idegbe or nrachi, is entitled to inherit both movable and immovable property from her deceased father's estate. The legal interest vests in her until she gives birth to her own children. However, if she bears sons and daughters, the sons rather than the daughters succeed her in accordance with the rule of primogeniture.

126 Muojekwu v Ejikeme, above at note 124 at 410.

127 See CEDAW Committee General Recommendation No. 25: Temporary Special Measures A/59/ 38 Part I; CEDAW/C/2004/I/WP 1/Rev.1 (2004). 
and in the benefits of development and all programmes related to the realization of all human rights.

As noted above, the custom of polygyny discriminates against women, for example:

\begin{abstract}
"This custom can place women at a severe disadvantage by treating wives as commodities to be bought and sold. Even in cases where women's rights to inheritance and child support are recognised, polygamy leaves less to split among the wives. Polygamy is also one of the major reasons African men have difficulty supporting their families placing heavier burdens on women to produce and support their children...A major problem exists since women bear a risk of getting infected [with HIV/AIDS] by men who have multiple partners/wives". ${ }^{128}$
\end{abstract}

Viewed in this context, article 6(c) of the African Women's Rights Protocol may be interpreted as imposing an obligation on the African states parties to move as expeditiously and effectively as possible towards that goal of monogamy (and thus an implied obligation to eliminate polygamy). If the Protocol was to be read in such a way as not to establish such an obligation to move towards monogamy, it would be largely deprived of its raison d'etre since polygyny discriminates against women and thus goes to the root of equality and non-discrimination.

\title{
Divorce
}

Traditional divorce law in many states in Africa discriminates against women. For example, in Egypt, shari'a is the primary source of legislation and practices that conflict with the government's interpretation of shari'a are prohibited. ${ }^{129}$ Women seeking divorce through unilateral repudiation by virtue of Act No 1 of 2000 ( $k h u l$ ) must in all cases forego their rights to financial support and, in particular, to their dowries. ${ }^{130}$ This leads to

128 AK Wing and TM Smith "The new African Union and women's rights" (2003) 13 Transnational Law \& Contemporary Problems 33 at 40, 45 (footnotes omitted). See also EN Mayambala "Changing the terms of the debate: polygamy and the rights of women in Kenya and Uganda" (1997) 3/2 East African Journal of Peace and Human Rights 200. But see MC Ali “Who practices polygamy?", available at: < http://www.polygamy.com/Islam/ Who-Practices-Polygamy.htm $>$ (accessed 17 March 2006), who argues that: "The truth of the matter is that monogamy protects men, allowing them to 'play around' without responsibility... Men are the ones protected by monogamy while women continue to be victims of men's desires. Polygamy is very much opposed by the male dominated society because it would force men to face up to responsibility and fidelity. It would force them to take responsibility for their polygamous inclinations and would protect and provide for women and children".

129 See entry on "Egypt" in Bureau of Democracy, Human Rights, and Labor International Religious Freedom Report 2006, available at: < http://www.state.gov/g/drl/rls/irf/2006/ 71420.htm $>$ (last accessed 15 November 2006).

130 HRC Concluding Observations: Egypt CCPR/CO/76/EGY(28/11/2002) at para 8; CEDAW Concluding Observations: Egypt A/56/38 (2 February 2001) at para 328. 
financial discrimination against women and may bar women from seeking divorce through unilateral repudiation. In some states, women have to meet stricter evidentiary standards than men to prove grounds for divorce. In Uganda, for example, before 15 October 2004, males were able to divorce their wives solely on the grounds of adultery, whereas for a wife to petition for divorce, she had to prove adultery plus an additional ground.131 Uganda's Constitutional Court, on 10 March 2004, held that these provisions were inconsistent with articles 21 (equal protection), 31 (equal rights in marriage) and 33 (right to dignity) of the 1995 Ugandan Constitution. ${ }^{132}$ The court ordered all grounds for divorce mentioned in the Divorce Act to be available to both men and women equally. ${ }^{133}$ This is a welcome development consistent with the right for "women and men [to] enjoy the same rights in case of separation, divorce or annulment of marriage". ${ }^{134}$

However, it is important to note that even if adultery as a ground for divorce is available to both men and women, the domestic law sets out different standards of adultery for husbands and wives. ${ }^{135}$ In the case of Uganda, adultery is currently classified as one of the "Offences against Morality", meaning it is one of the mechanisms that sets sexual moral standards for married couples. ${ }^{136}$ Under section 154(1) of Uganda's Penal Code, a husband is guilty of adultery if he has sexual intercourse with a "married woman" other than his wife. But a wife, under section 154(2), commits adultery when she has sexual intercourse with "any man" other than her husband (married or not married)! Here, the law clearly imposes double standards on sexual norms. It endorses male sexual promiscuity (as long as a married man is not trespassing on another man's "property"), but imposes stricter control over women's sexuality. Thus, the law ensures that women remain monogamous and stick to one partner, and sanctions the polygynous sexuality of men. In addition, the husband in the case of an adulteress wife is said to be an "aggrieved party" whereas the wife of an adulterous husband is not. ${ }^{137}$ Accordingly, a convicted adulterer must pay compensation to the husband of the adulteress. ${ }^{138}$ The fact that only an aggrieved husband can obtain compensation reduces a married woman to the position of her husband's property who should be compensated for the

131 These included: incest, bigamy, polygamy, rape, sodomy, bestiality, cruelty or desertion. See the Divorce Act (cap 249), Laws of Uganda, 1964, sec 4(2)(b).

132 Constitutional Court of Uganda at Kampala Uganda Association of Women Lawyers v The Attorney General Constitutional Petition No 2 of 2003 (10 March 2004). Art 21 states: “All persons are equal before and under the law in all spheres of political, economic, social and cultural life and in every other respect and shall enjoy equal protection of the law".

133 Ibid.

134 African Women's Rights Protocol art 7.

135 See, eg, The Penal Code Act (chap 120, Laws of Uganda).

136 Ibid.

137 CEDAW Third Periodic Reports of States Parties: Uganda CEDAW/C/UGA/3 (3 July 2000) at 67.

138 Ibid. 
damage occasioned to it. ${ }^{139}$ It also ensures that husbands exercise almost rights of legal ownership over wives, thus reducing married women to the status of "objects" or being held in "slavery". ${ }^{140}$ Clearly, this means of determining human relations is both archaic and discriminatory against women. ${ }^{141}$

\title{
CONCLUSION: THE DUTY TO UPROOT CULTURAL OBSTACLES
}

This article has focused on only a handful of the many cultural issues that arise in the debate over the protection and promotion of women's human rights in Africa. What is clear is that despite a wide range of human rights instruments protecting the human rights of African women, these rights are now between light and shadow. This is because although the Protocol to the ACHPR on the Rights of Women in Africa sets a strong legal basis for the protection of the human rights of women at a regional level, it remains replete with difficulty in its application. As noted above, more than three years after the adoption of the Women's Rights Protocol, only 17 (out of 53) African states have ratified it. In addition, harmful traditional practices and theological premises (broadly speaking, "culture") have had a disproportionately negative effect on the realization of women's human rights. As the UN Human Rights Committee (HRC) observed:

\begin{abstract}
"Inequality in the enjoyment of rights by women throughout the world is deeply embedded in tradition, history and culture, including religious attitudes. ... States parties should ensure that traditional, historical, religious or cultural attitudes are not used to justify violations of women's right to equality before the law and to equal enjoyment of all Covenant [ICCPR] rights". ${ }^{142}$
\end{abstract}

The key question is what are the underlying dynamics that make culture as an obstacle to women's human rights in Africa so difficult to change? The simple answer is that cultural obstacles in Africa are deeply entrenched and most states have not adopted immediate and effective measures, particularly in the fields of teaching, education and information, to combat discrimination against women. As required by both CEDAW (article 5(a)) and the Protocol to the ACHPR on the Rights of Women in Africa (articles 2 and 12), it is now time for states to take "appropriate measures" to modify

139 Ibid.

140 According to art 1 of the Slavery Convention, 60 LNTS 253, entered into force 9 March 1927 , which corresponds to the "classic" meaning of slavery as it was practised for centuries, "slavery is the status or condition of a person over whom any or all of the powers attaching to the right of ownership are exercised".

141 See S Tamale "Adultery law violates our constitution” (11 April 2006) The New Vision, Kampala; O Oloya "Uganda: adultery law is archaic, oppressive to women" (12 April 2006) The New Vision, Kampala.

142 HRC General Comment 28 "Equality of Rights Between Men and Women" (Article 3), UN Doc CCPR/C/21/Rev1/Add 10 (2000) at para 24. 
"social and cultural patterns of conduct" to eliminate prejudices and practices based on the idea of the inferiority of women or on stereotyped roles of either sex. It is, therefore, necessary for African states to give urgent attention to the general duty of states to modify the social and cultural patterns of conduct of women and men through public education. ${ }^{143}$

However high the barriers, change is possible. What is so deeply-rooted may be uprooted or transformed, especially through public education: stereotypical gender roles can be challenged through textbooks, academic instruction and patterns of participation in the education process. Continuous education will help to encourage the participation of women, overcome entrenched forms of resistance and transform certain cultural practices. Education is vital for the establishment of a culture where human rights are understood, respected and promoted. With respect to some cultural practices, such as polygyny, internal dialogue with the community between proponents and opponents of the practice may open a path to change more effective than a state's effort to criminalize the practice. ${ }^{144}$

It must be realized that in an era of globalization, it is no longer enough to focus only on the state as the bearer of human rights obligations. A wide range of non-state actors (NSAs), including individuals, groups, corporations and other entities, should equally be obliged to respect and protect (where appropriate) the human rights of women. Some human rights treaties make this duty specific. For example, articles 2(e), 2(f) and 11 of CEDAW oblige states to take "appropriate measures" to eliminate discrimination against women by "any person, organization or enterprise". Under article 25(a) of the Protocol to the ACHPR on the Rights of Women in Africa, states parties undertake to "provide for appropriate remedies to any woman whose rights or freedoms, as herein recognised, have been violated". These remedies may be against the state or NSAs (such as a discriminatory private employer in hiring, remuneration and promotion).

There is, consequently, a need to interpret the African Women's Rights Protocol as a living instrument. This requires the African Court to develop a framework within which the accountability for violations of human rights of women should not only be that of the state but also that of other actors. In this context, it would be possible to bring claims of human rights violations of women's human rights not only against the state, but also directly against NSAs. This would help to address discrimination in the "private" sphere of the workplace, school, home and elsewhere. It would, therefore, be beneficial if the African Court were to seek to develop the Protocol in an objective and dynamic manner, by taking into account the increasingly higher standards for the protection of human rights. In this respect, it is useful to view culture as a dynamic aspect of every state's social

143 Protocol to the ACHPR on the Rights of Women in Africa art 2(2). See also CEDAW art 10(c); CERD art 7; CRC art 12(1).

144 See A An Na'im "State responsibility under international human rights law to change religious and customary law" in R Cook (ed) Human Rights Of Women: National and International Perspectives (1994, University of Pennsylvania Press) chap 7. 
fabric and life, and therefore subject to change. As Steiner writes, "Culture is plastic, made and remade through the course of history, not unshakable and essentialist in character but in many respects contingent, open to evolution and to more radical change through purposeful human agency informed by human rights ideals". ${ }^{145}$

Viewed in this context, cultural practices discriminatory against women must be grasped not as static objects, but as historical processes. Nondiscriminatory customary law and human rights, rather than being mutually exclusive, can and should complement each other. The cases of Bhe in South Africa, ${ }^{146}$ and Mojekwu in Nigeria provide some good examples of this. ${ }^{147}$ As noted above, both courts applied human rights standards of equality and non-discrimination, without discarding culture. While it is necessary to uphold cultural life and diversity, it is equally essential to uphold the human dignity of all women, and of all men, on the basis of equality. Whether the African Court can live up to this expectation remains to be seen. Of course, it is unlikely that the Court will meet this aim if the African Union does not provide it with the adequate material, financial and moral support to allow it to function independently. What is clear, however, is that domestic courts can play a key role in affirming the human rights of women. The South African example in the Bhe case clearly demonstrates this point.

Finally, it must be recognized that passing, and even enforcing, laws or treaties protecting the human rights of women, while useful, does not guarantee equality. As shown above, despite the existence of several international instruments prohibiting discrimination against women and mandating equality, discrimination and inequality persist in practice. Indeed, the great irony is that women have been charged with, and have often found security in, maintaining discriminatory customs and tradition, thus institutionalizing the discrimination against themselves through the education and socialization of children. ${ }^{148}$ Therefore, while it is necessary to pay more attention to further implementation of the existing human rights instruments, educating the wider public about the need to eliminate customary practices which discriminate against women at the global, regional, national and local levels would strengthen the cause of women's human rights in Africa. To appreciate this point, one needs to ask a few simple questions: how many African women have heard about the existence, let alone the content, of the Protocol to the African Charter on

145 HJ Steiner "International protection of human rights" in MD Evans (ed) International Law (2nd ed, 2006, Oxford University Press) 753 at 777.

146 Bhe v Magistrate Khayelitsha and Others, above at note 123. For a discussion, see E Grant "Human rights, cultural diversity and customary law in South Africa" (2006) 50/1 Journal of African Law 2.

147 See note 124 above.

148 See Keynote Address by HE Mrs Julia Dolly Joiner, commissioner for political affairs, Commission of the African Union, Symposium on the African Union's Protocol on the Rights of Women in Africa (21 January 2006, Khartoum), on file with the author. 
Human and Peoples' Rights on the Rights of Women in Africa? Why do the majority of the African women "support" the very practices that discriminate against them? Do these questions need further research?

Whatever the answers, it is suggested that African states and other actors should increase efforts, individually and through international cooperation, to design and implement comprehensive education and awarenessraising programmes targeting women and men at all levels of society, with a view to creating an enabling and supportive environment within which to transform and change discriminatory laws, customs and stereotypes and allowing women to exercise their human rights. The promotion of gender equality must be made an explicit component of all national development strategies, policies and programmes, in particular those aimed at poverty alleviation and sustainable development, including poverty reduction strategies. Special attention must be made to the needs of rural women ${ }^{149}$ - who often lack access to adequate health services, access to education, clean water and sanitation services, access to justice and access to credit facilities - and women heads of household.

149 R Nakayi et al “The Women's Movement in Africa: creative initiatives and lessons learnt" (2005) 11/2 East African Journal of Peace E Human Rights 265 at 299 and 302, noting that: "Elitism has blurred the goals of the Women's Movement [in Africa]. Often the elite women seem to be out of touch with the issues that affect rural poor women ... There is a need to find ways and means of making rural and other disadvantaged women more visible in the movement". 